\title{
Genetic rearrangements and gene amplification in Escherichia coli: DNA sequences at the junctures of amplified gene fusions
}

\author{
Susan K. Whoriskey, Van-Ha Nghiem, Phaik-Mooi Leong, Jean-Michel Masson, and Jeffrey H. Miller \\ Molecular Biology Institute and Department of Biology, University of California, Los Angeles, California 90024 USA
}

\begin{abstract}
We describe gene fusions that result from genetic duplications of 5-20 kb, which are amplified 50- to 100-fold. Because one end point of the fusion lies within the sequenced lacI gene, the new junctures created by the duplications are readily identified. Using a procedure for dideoxy sequencing of double-stranded DNA, we show that the duplications occur almost exclusively at short sequence repeats (less than $15 \mathrm{bp}$ ), sometimes involving broken homologies, in the 30 cases examined. Most of the duplications place the lacI-Z encoded hybrid repressor- $\beta$-galactosidase protein under the control of a downstream promoter, resulting in the production of a more complex hybrid protein with $\beta$-galactosidase activity. In some cases the fusion occurs with the lacY or the lacA gene, which suggests that silent promoters can be uncovered by gene fusion and subsequent amplification. In some ways this system represents a bacterial analog to chromosomal rearrangements of oncogenes in higher cells, since here the expression of a silent gene is the result of a genetic rearrangement that is followed by amplification during selected growth.
\end{abstract}

[Key Words: Gene fusions; gene amplification; Escherichia coli]

Received February 4, 1987; accepted February 24, 1987.

Large genetic rearrangements have been studied for many years (Auerbach 1976), but relatively little is known about them at the DNA sequence level, and few of the enzymatic pathways involved have been elucidated. Although transposable genetic elements can mediate certain rearrangements (see Shapiro 1983), many rearrangements of the genome occur without the obvious participation of such elements. It is now recognized that rearrangements may play a central role in many biological processes, including development (Long and Dawid 1980; Spradling 1981; Bostock 1984; Haselkorn et al. 1986), control of gene expression (Varmus 1984; Murnane 1986), differentiation (Tonegawa 1983; Bostock 1984), antibody formation (Tonegawa 1983), antigenic variation (Van der Ploeg et al. 1984; Segal et al. 1985), and evolution (Riley and Anilionis 1978; Sager et al. 1985; Schimke et al. 1986). Recent work with oncogenes has strongly implicated genetic rearrangements in the origin of certain human cancers (Land et al. 1983; Leder et al. 1983; Marx 1984), an idea that had been postulated previously (see, for instance, Cairns 1981). With respect to specific types of rearrangements, gene amplification in mammalian cells is responsible for observed resistance to chemotheropeutic agents. For instance, methotrexate resistance results from amplification of the dihydrofolate reductase gene in cultured cells (Schimke 1984) and in human patients (Horns et al.
1984). Amplification has itself been implicated in the origin of cancer, as evidenced by correlation of the amplification of the $\mathbf{n}-m y c$ oncogene with tumorigenesis and tumor progression for human neuroblastomas (Alitalo 1984; Schwab et al. 1984; Gilbert 1985). Clearly, it is important to understand the pathways that lead to different kinds of genetic rearrangements, and in particular those responsible for gene amplification.

The complexity of many eukaryotic systems has made it difficult to study certain mutational processes, and particularly genetic rearrangements, at the DNA sequence level. Bacterial systems offer the possibility of carrying out high-resolution genetic studies together with detailed DNA sequence analyses. Mutational pathways can be understood at the sequence level in bacteria and then be compared with their counterparts in eukaryotic systems. Also, bacterial genes can be introduced into mammalian cells via shuttle vectors and rearrangements can be analyzed subsequently in bacterial hosts (Calos et al. 1983; Miller et al. 1984).

We have characterized a series of high amplifications of 8- to $37-\mathrm{kb}$ regions of the Escherichia coli chromosome surrounding the lac region on an $\mathrm{F}^{\prime}$ plasmid (Tlsty et al. 1984). Restriction enzyme analysis demonstrates that the amplified units, which are repeated in tandem 40-200 times, can occur at many different points. This can be seen in Figure 1, which shows the extent of 50 
amplified units that we mapped (S.K. Whoriskey and J.H. Miller, unpubl.), extending the data of Tlsty et al. (1984). Our goal is to determine the mechanism that causes these rearrangements. A necessary first step is to determine the sequences at the junctures of the amplified units. With an understanding of the DNA sequence requirements of gene amplifications we can then pursue the enzymatic pathway(s) involved in their formation. The task involved in determining juncture sequences is outlined in Figure 2, which depicts in more detail one of the amplification events portrayed in Figure 1. At the top of the figure the region to be duplicated (and subsequently amplified) is shown, together with surrounding sequences, indicated by the letters $a, b, x$, and $y$. In the wild-type, the sequence segment a borders segment $b$, and much further away, the segment labeled $x$ borders segment $y$. In the middle of the figure the consequences of a duplication are shown. It can be seen that this rearrangement creates a unique "juncture" at which the sequence segment $\mathrm{x}$ now borders the sequence segment $\mathrm{b}$. This $\mathrm{x}-\mathrm{b}$ juncture is unique to every duplication event. Amplification of the duplication, represented in the bottom of Figure 1, results in the amplification of the $\mathrm{x}-\mathrm{b}$ fused segment.

Our first aim is to elucidate the sequence at the junctures of numerous duplication-amplification events and to determine whether there are any distinguishing characteristics of these sequences. For instance, such re- arrangements might occur at specific sequences, at sequences with secondary structure possibilities, or at short homologies such as seen in the case of deletions (see Albertini et al. 1982, and references therein). Alternatively, these events might be generated at sequences lacking any obvious characteristics. To determine the juncture sequences, however, we would have to detect and clone juncture fragments and compare them with the wild-type sequences on either side of the duplicated segment (see Fig. 2). Since the rearrangements detected so far are spread out over a $40-\mathrm{kb}$ range (Fig. 1 and Tlsty et al. 1984), which has not been characterized at the DNA sequence level, elucidating the nature of the sequences at the junctures in 20-30 examples would be a formidable task. Therefore, we have sought a method that would generate duplication-amplifications with one end in a known DNA segment. We have devised a genetic selection that allows us to focus on such a subset of rearrangement events. Here we describe the sequence analysis of amplification events in which the junctures terminate in the lacI gene, which permits rapid determination of the sequence surrounding the juncture points.

\section{Results}

Selection for duplication-amplifications

Figure 3 diagrams the $l a c$ region carried on an $\mathrm{F}^{\prime} l a c p r o B$ episome in strain JM177, which also contains a chromo-

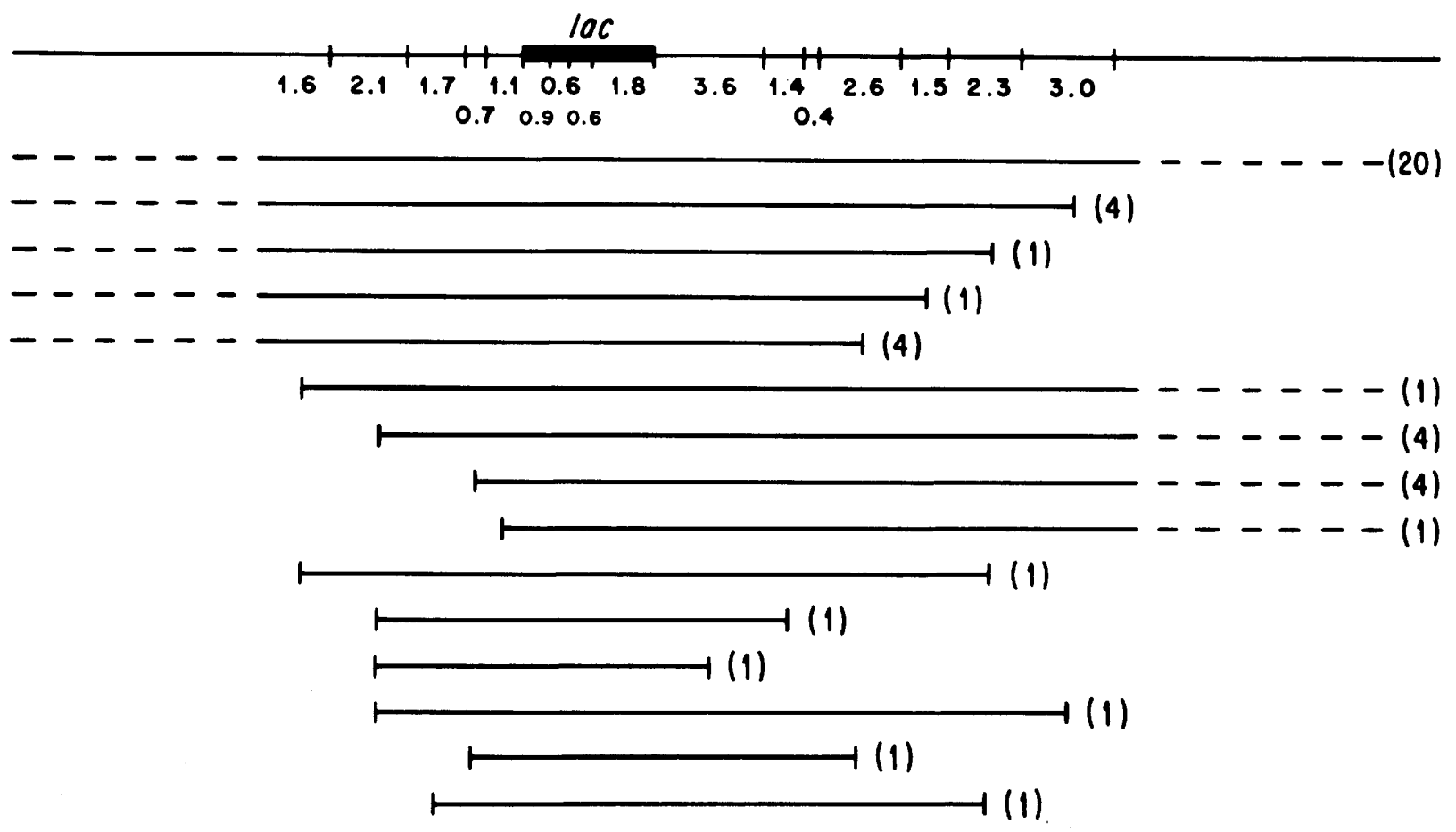

Figure 1. Extent of the amplified DNA in independently occurring mutants. DNA was isolated from several independent, unstable revertants of a lacI-Z, fusion strain carrying the amber mutation $X 13$, and digested with HincII. The restriction pattern of the amplified DNA was compared with the HincII pattern of plasmid pGM11 to determine the amplified region. The top line represents the HincII pattern for pGM11. The lines below represent the amplified regions from several mutants, with the numbers in parentheses indicating the number of independent isolates with the same mapping pattern. Dotted lines indicate end points of the amplified DNA that fall outside of the mapped region of pGMll (see also Tlsty et al. 1984). 

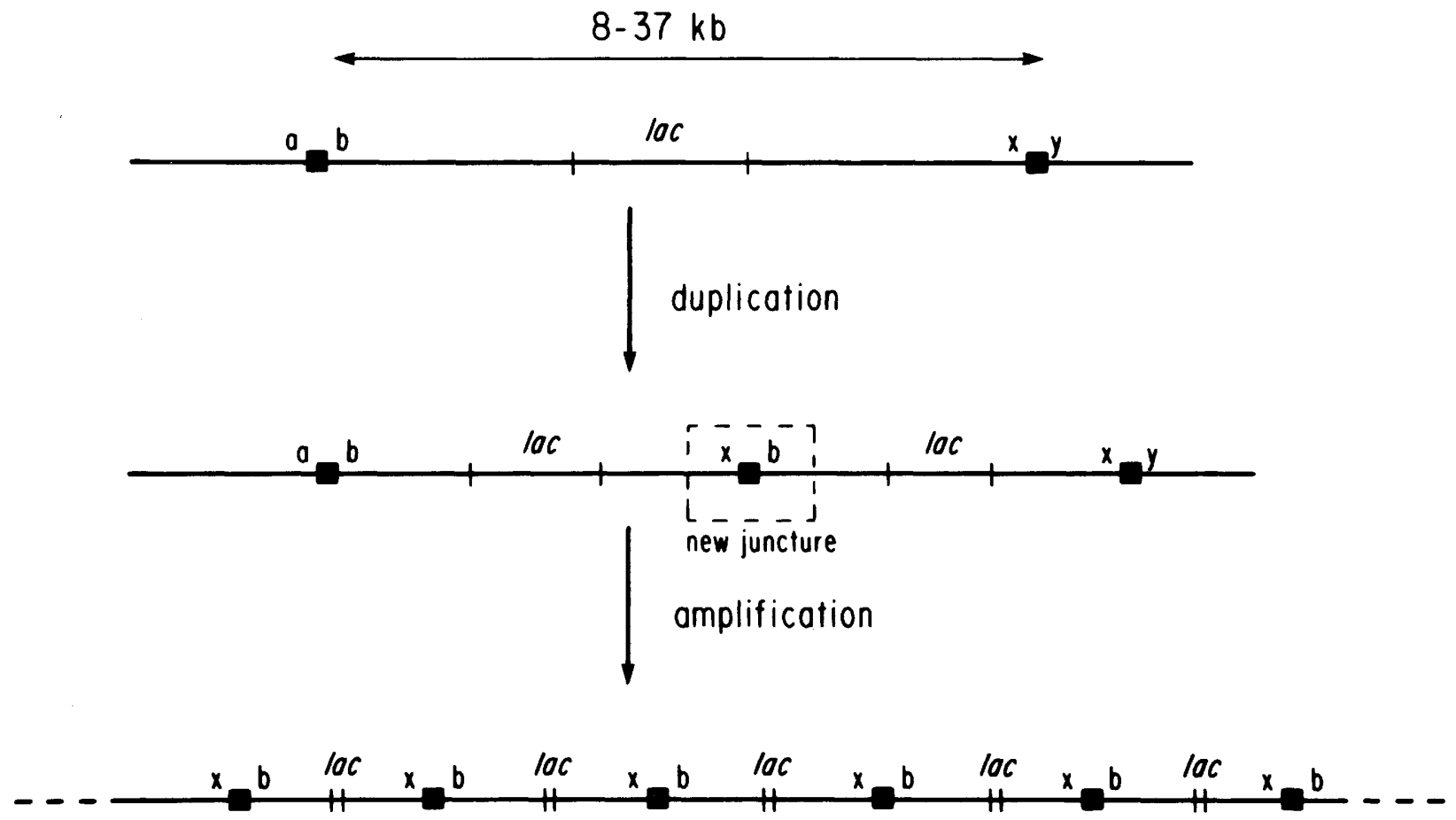

Figure 2. Schematic representation of the formation and amplification of a novel juncture. A tandem duplication of DNA sequences, including the lactose operon, would result in the formation of a new juncture. Sequences $b$ and $x$, widely separated in the wild-type chromosome, would become contiguous. A comparison of the DNA sequence at the $x$-b juncture with the wild-type $x$ and $b$ sequences would reveal the exact nucleotides at the point of rearrangement.

somal deletion for lacproB. Here, the lacI and lacZ genes are fused, as previously described (Müller-Hill and Kania 1974; Brake et al. 1978), resulting in the production of a hybrid repressor- $\beta$-galactosidase protein with full $\beta$-galactosidase activity, under the control of the $1 \mathrm{acI}{ }^{\mathrm{Q}}$ promoter (Calos et al. 1978 and references therein). However, the promoter for lacI has been inactivated by a deletion of $4 \mathrm{bp}$ (UJ177; Calos and Miller 1980). Therefore, transcription is not initiated at the $I$ promoter, and the lac enzymes are not produced. Revertants to $\mathrm{Lac}^{+}$must express both the hybrid $Z$ gene and the $Y$ gene, and thus must be under the control of a new promoter. When

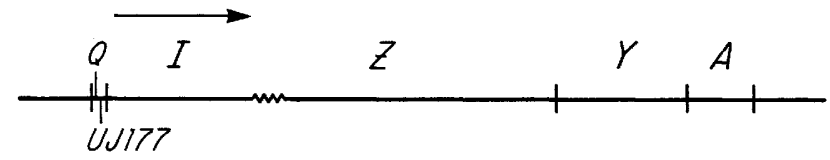

Figure 3. The lacI-Z fusion carrying promoter mutation U1177. A deletion described by Müller-Hill and Kania 1974 (see also Brake et al. 1978) results in an in-frame $I-Z$ gene fusion, under the control of the lacI $I^{Q}$ promoter (see Calos 1978). The carboxy-terminal 4 amino acid residues of repressor and the amino-terminal 23 residues of $\beta$-galactosidase are absent from the resulting functional, hybrid protein. The UJ177 mutation (Calos and Miller 1980) is a 4-bp deletion in the -10 region of the $l a c I^{Q}$ promoter. This mutation greatly reduces expression of the lac operon, resulting in a $\mathrm{Lac}^{-}$phenotype when in combination with the $I-Z$ fusion deletion. strain JM177 is plated on lactose minimal medium, we detect $\mathrm{Lac}^{+}$revertants at approximately $10^{-7}$ in the population. Some of the revertants are deletions, as shown by Southern analysis (data not shown), which probably fuse the $I$ gene to an upstream operon. However, a major class of revertants appears somewhat unstable in the absence of the $\mathrm{Lac}^{+}$selection, generating $\mathrm{Lac}^{-}$colonies at a visible level when plated on indicator media. Further analysis, described below, demonstrates that most of the unstable revertants contain duplications of the type depicted in Figure 4.

It can be seen from Figure 4 that the duplications create a novel juncture that can result in fusion to a "downstream" operon oriented in the same direction. Fusions of this type have been previously reported by Anderson and Roth (1978a) in Salmonella typhimurium. If the expression of the new fused operon were strong enough, then a single copy of the fused operon would be sufficient to allow growth on lactose. However, in all of the cases we examined, the level of gene expression of a simple duplication is not sufficient, since examination of the DNA from the $\mathrm{Lac}^{+}$unstable revertants demonstrates that the DNA is highly amplified.

\section{Gene amplification}

Figure 5 shows the HincII digestion pattern for some of the $\mathrm{Lac}^{+}$revertants. The pattern of intense bands permits us to determine: (1) that the lac DNA sequences are amplified in tandem; (2) the size of the amplified re- 
Whoriskey et al.

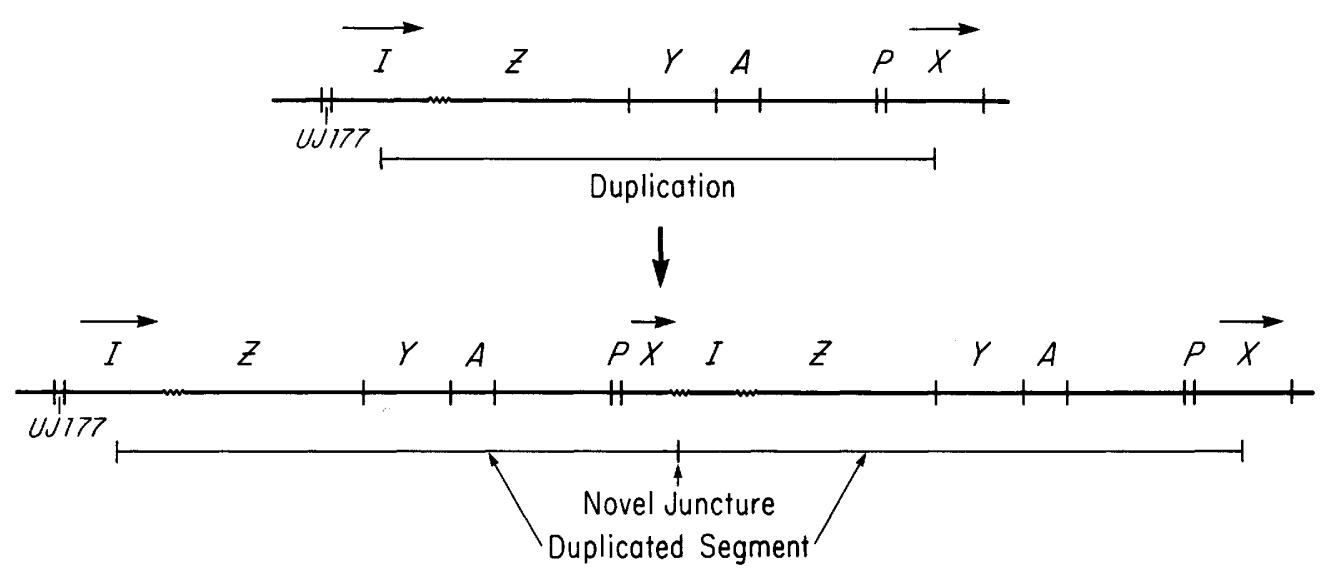

Figure 4. Schematic representation of a duplication that introduces a new promoter upstream of the lac operon. A tandem duplication of a DNA segment (the underlined portion), with one end point in the lacI gene and the other end point downstream in an unidentified operon $X$ with promoter $P$, would result in the formation of a novel juncture and an $X-I$ gene fusion event. This genetic rearrangement would juxtapose a promoter upstream of the lac operon. Amplification of the duplicated segment could uncover low-level functional promoters.

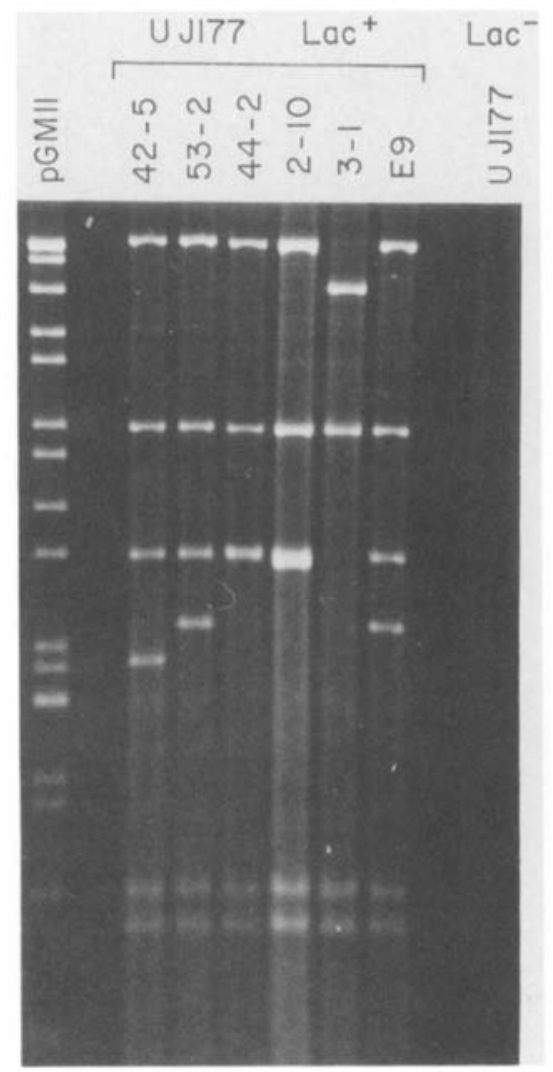

Figure 5. Restriction enzyme digestion of the amplified DNA sequences. DNA from six $\mathrm{Lac}^{+}$unstable revertants of JM177 was prepared, digested with restriction endonuclease HincII, separated by electrophoresis in a $1.4 \%$ agarose gel, and stained with ethidium bromide, as described in Materials and methods. Plasmid pGM11 is a pBR322 derivative containing the lac region and flanking sequences (see Galas et al. 1980). This plasmid does not contain the lacI- $Z$ fusion deletion, but instead contains the lac promoter-operator region. Samples 42-5, 53-2, 44-2, 2-10, 3-1, and $\mathrm{E} 9$ are $\mathrm{Lac}^{+}$, unstable, amplification revertants of JMI77. Sample UJ177 is the $\mathrm{Lac}^{-}$starting strain. gion; (3) the HincII end points of the amplified DNA; and (4) the size of the unique HincII juncture fragment.

Figure 6 displays the end points of the duplicationamplifications found in JM177 Lac' revertants. Most of the duplication-amplification junctures end within the lacI gene, as expected for operon fusions of the type shown in Figure 4.

\section{Sequences at amplification junctures}

We determined the DNA sequence surrounding each juncture by the following strategy:

1. Partially purified E. coli DNA, which included both chromosomal and episomal DNA, was prepared from each revertant carrying an amplified lac region.

2. DNA preparations were used as a double-stranded template for dideoxy sequencing with a series of 5 '-endlabeled synthetic oligonucleotide primers in lacI, using the enzyme AMV reverse transcriptase.

3. The resulting DNA sequences were compared with the known wild-type lacI (Farabaugh 1978), lacY (Büchel et al. 1980), and lacA (Hediger et al. 1985) sequences, or with sequences of the surrounding region obtained during this study.

We employed the following strategy. A series of synthetic primers 17-20 bp long were synthesized at approximately 150 -bp intervals in the $I$ gene, with the $5^{\prime}$ to $3^{\prime}$ direction pointing toward the fusion joint. Initial restriction mapping (see Materials and methods) predicted which 300- to 400-bp segment of the $I$ gene contained the fusion point, allowing use of a limited set of primers for DNA sequence analysis. Our sequencing procedure for double-stranded DNA, described in detail in Materials and methods, is a modification of a procedure by Huibregtse and Engelke (1985). We use as template partially purified, digested, episomal DNA; no cloning into plasmid DNA is required. The DNA is denatured at $95^{\circ} \mathrm{C}$ and immediately transferred to $50^{\circ} \mathrm{C}$. Standard dideoxy sequencing using $5^{\prime}$-end-labeled 17 -mer oligonu- 


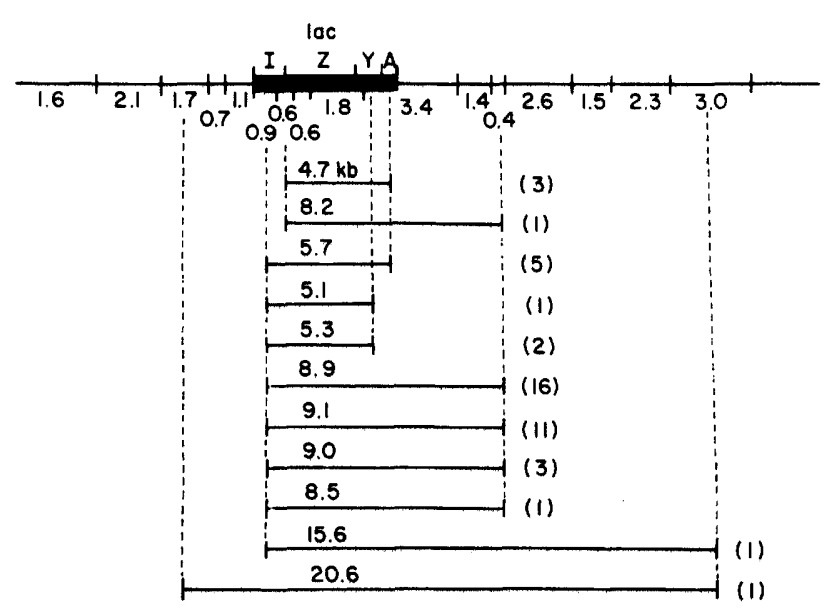

Figure 6. Extent of amplified DNA sequences from several independently isolated mutants. The HincII restriction pattern was determined for 45 independent amplification revertants of JM177, by comparing the amplified bands present in a restriction enzyme digestion of the mutant to the pGMll HincII map. The top line is the HincII restriction map of plasmid pGM11. In determining the extent of the amplified DNA in the mutants, the absence of the next distal fragment indicates that the end point of the amplified unit is within that fragment. The numbers in parentheses indicate the number of isolates with the same mapping pattern.

cleotides as primers is carried out at $50^{\circ} \mathrm{C}$ using AMV reverse transcriptase. The reaction is carried out in the absence of any carrier DNA. The resolution afforded by this modified procedure allows unambiguous sequence determination of double-stranded DNA. Figure 7 shows a sample sequencing gel from one of the fusion junctures. The DNA preparation was of total chromosomal and episomal DNA, digested wih HincII, from a strain with highly amplified episomal DNA segments. DNA sequencing gels of similar resolution have been obtained with multicopy plasmid DNA and even with single-copy $F^{\prime}$ DNA (data not shown).

The size of the HincII restriction fragment containing the fusion juncture allows us to predict the approximate end point of the duplication-amplification (Figs. 5 and 6). Using the known lacI sequence (Farabaugh 1978) we can determine at which nucleotide the sequence reflects a fusion of part of lacI to a new genetic region. We initially focused on those fragments that included the lacY and lacA regions, since a significant portion of the surrounding DNA has been sequenced (Büchel et al. 1980; Hediger et al. 1985). Subsequently, other regions were included in our analysis.

Twenty-eight of the 30 junctures that we analyzed were created at repeated sequences, as evidenced by the example shown in Figure 8. Here, a broken homology of $9 \mathrm{bp}$ is found between a sequence in the lacl gene and a sequence downstream from lac within the $0.4 \mathrm{HincII}$ fragment depicted in Figure 6. The duplication of a $9-\mathrm{kb}$ segment occurred at this sequence, producing the arrangement shown in Figure 8. The duplicated segment is amplified 50-100 times in the $\mathrm{Lac}^{+}$revertant. Figures 9 and 10 depict all of the sequences at the duplicationamplification junctures of 30 randomly sequenced independent isolates. In some cases more extended broken homologies can be defined. We have identified nine different juncture sequences. There are repeat occurrences of rearrangements at four of the nine junctures.

\section{Molecular consequences of gene fusions}

The fusions created by the duplications studied here raise several interesting points concerning gene expression. For instance, where are the active promoters in the duplication fusions that end within $l a c Y$ and $l a c A$, and what is their function in the unamplified, wild-type chromosome? Mulligan and McClure (1986) have performed a computer analysis of the occurrence of consensus promoter sites in DNA, and have shown that two sites in particular in lacY have significantly high scores

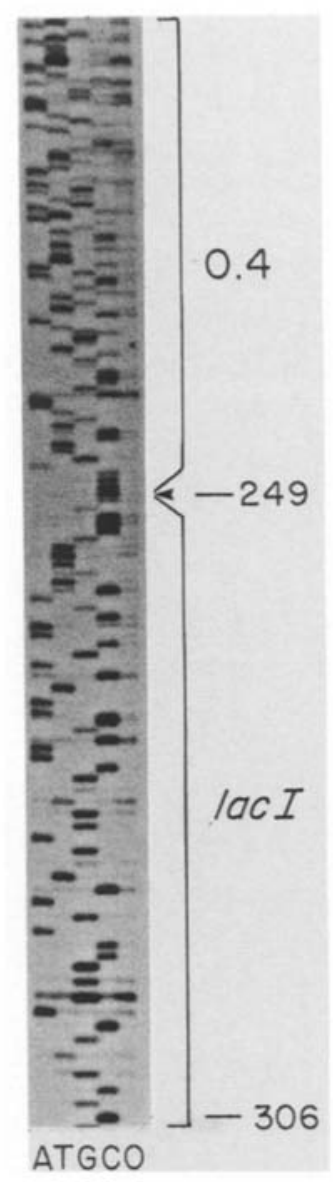

Figure 7. DNA sequence of the juncture of an amplification mutant obtained from double-stranded, total E. coli DNA. Total, E. coli DNA, digested with HincII restriction endonuclease, was heat-denatured and annealed to a 5 '-end-labeled oligonucleotide complementary to nucleotides 363-347 of the lacl gene, as described in Materials and methods. The primer was extended using AMV reverse transcriptase in a chain-terminator reaction, across the fusion juncture point (see Fig. 3). In lane 0 , no dideoxynucleotide was added. The DNA sequence is wild-type lacI up to nucleotide 249 and then shifts to the wildtype sequence of the downstream HincII 0.4-kb fragment. 
Whoriskey et al.

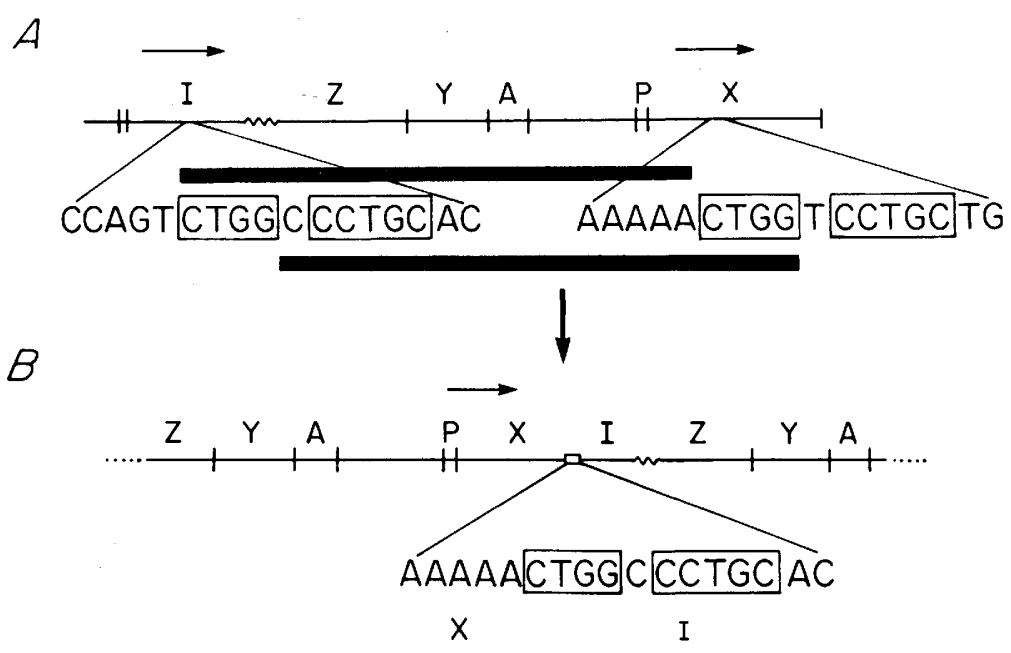

Figure 8. Sequences involved in the formation of a duplication. A duplication, shown in $A$, occurs between short, partial homologies. A match of 9 out of $10 \mathrm{bp}$ is found both in the wild-type sequence of the lacI gene and downstream within a HincII 0.4-kb fragment, designated as part of operon $X$ here. A 9-kb duplication between these homologies produces the rearrangement shown in $B$. The heavy black lines indicate the duplicated region and show that we cannot determine which one of the homologies at the end points of the duplication is the one present at the fusion juncture. An $X-I$ gene fusion is formed as a result of the duplication.

in their analysis. As can be seen from Figure 11, a promoter in lacY would result in two novel hybrid proteins (see legend to Fig. 11). Also, because there are no transcription termination signals within the fused segments, each transcript could proceed into the next segment, and potentially continue on into many following segments.
This would result in large transcripts, differing in size by one amplified segment. Translation of multiple transcripts would offer the possibility of a second level of amplification of gene expression. In the extreme case, the combination of amplified transcription and translation could lead to a several thousandfold magnification

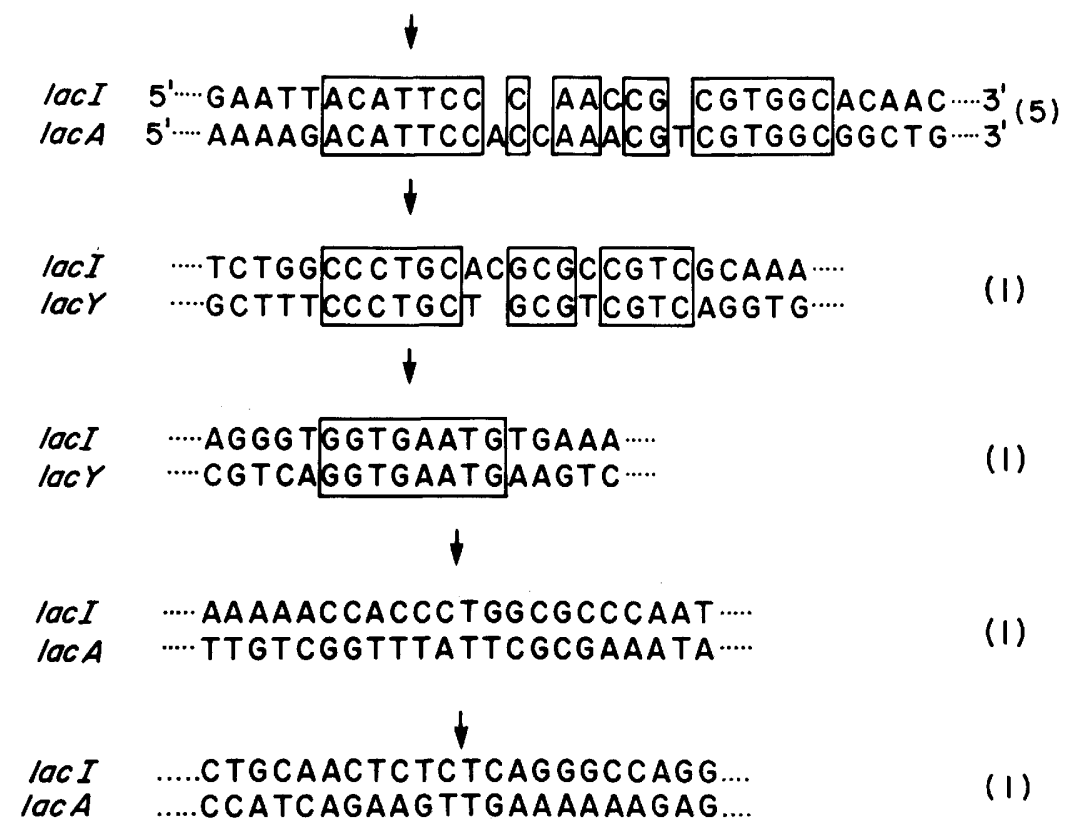

Figure 9. Nucleotide sequence of the junctions in which both end points are within the lac operon. The wild-type nucleotide sequence of the leftward lacI end point and the rightward lacY or lacA end point from several different cases are shown, aligned before recombination (see Fig. 7). The regions of homologies between the end points are boxed; the arrows show the box in which recombination occurred in the amplification revertants. The number of independent isolates with the same juncture sequence is indicated in parentheses. The regions of homology between the end points are boxed. The arrows show the box in which an in-frame recombination event occurred in the amplification revertants. 


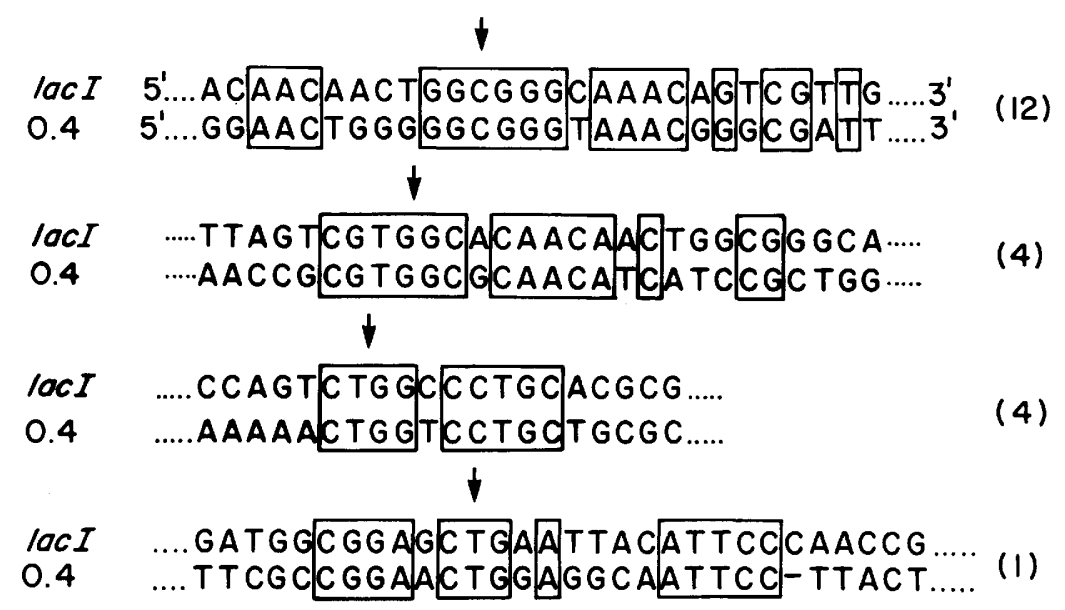

Figure 10. Nucleotide sequences of the junctions with the right-hand end point within the HincII 0.4 fragment. The nucleotide sequence of the left-hand lacI end point and the right-hand end point in the downstream HincII 0.4-kb fragment are aligned exactly as shown in Fig. 9.

of gene expression. In this manner, low-level promoters and inefficient translation start sites could still be utilized to provide sufficient levels of the required gene products.

\section{Discussion}

Gene amplifications have been described in a number of bacterial systems (Anderson and Roth 1978b; Edlund et al. 1979; Mekalanos 1983; Tlsty et al. 1984; Albertini and Galizzi 1985; Deretic 1986), and it is hoped that analyzing these events at the sequence level will help to elucidate the mechanism of amplification. In higher cells, amplification has been postulated to occur via discoordinate replication (see below). However, in bacteria it is possible to envision amplification as occurring in at least two distinct steps. In this model, the initial event generates a tandem duplication, and subsequent steps amplify the tandem copies by $r e c A$-mediated unequal recombination. Therefore, amplification cannot occur or is sharply reduced in $\mathrm{rec}^{-}$strains. This idea is supported by the fact that the amplification events described here are not detected in recA strains (see also Tlsty et al. 1984). It has not been clear whether the initial duplication event utilizes a pathway involving $r e c A$. Although duplications involving very large homologies fon the order of $1000 \mathrm{bp}$ ) are targets for unequal recombination mediated by recA (Anderson and Roth 1981), the recA requirement for duplications that do not involve large homologies appears to differ in different systems and for different types of duplications. It is important, therefore, to define the sequences at the junctures of specific duplications, and to correlate the nature of these sequences with the dependency on different host pathways.

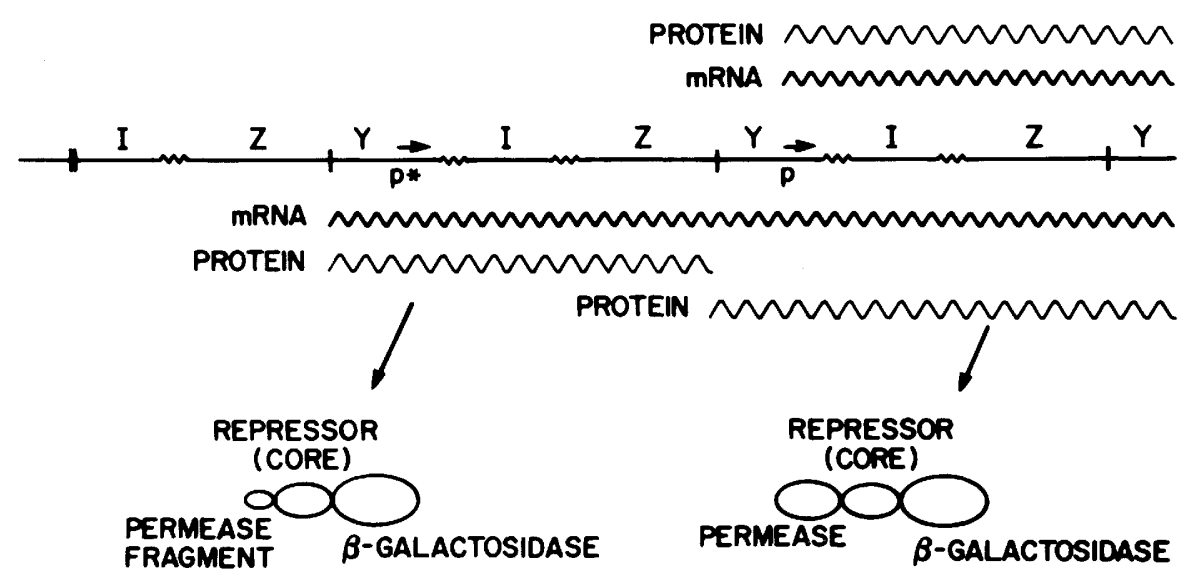

Figure 11. Molecular basis ror the phenotypic consequences of gene amplification. Amplification of a low-level promoter $(P)$ in $l a c Y$ could result in multiple transcripts (mRNA), due to initiation at each promoter site. The lack of transcription termination signals in this type of rearrangement could result in large transcripts, differing in size by one amplified unit. Translation of these transcripts would result in the formation of two trihybrid proteins. One hybrid would contain a carboxy-terminal permease protein fragment and the repressor- $\beta$-galactosidase moieties. The other hybrid would contain the repressor- $\beta$-galactosidase chimera and almost all of the permease protein, except for the carboxyl-terminal few amino acids. 
Normark and co-workers (Edlund and Normark 1981) have analyzed duplications and subsequent amplifications involving the $E$. coli $a m p C$ locus. The juncture point of one duplication event was shown to involve a 12-bp sequence that was repeated on each side of the ampC locus, $10 \mathrm{~kb}$ apart. We have employed lacI-Z fusion strains to detect amplifications of the lac region on an $F^{\prime}$ lacproB episome in E. coli (Tlsty et al. 1984). [Duplications that result in gene fusions have been described in S. typhimurium (Anderson and Roth 1978a)l. Here we describe amplification of gene duplications that fuse the lacI gene to a downstream sequence (see Fig. 4). Most of the duplication juncture points end within lacI, the sequence of which is known (Farabaugh 1978), thus facilitating the sequence analysis of the duplication events. By using double-stranded sequencing of amplified DNA with oligonucleotide primers corresponding to lacI sequences (Fig. 6), we can readily locate each duplication juncture. Comparison with the wild-type sequence for regions surrounding lacI allows determination of the sequence at which the duplications occurred. Sequencing directly from the chromosome eliminates anomalies that could be introduced by cloning out the juncture sequences.

We have sequenced junctures from 30 independently occurring duplication-amplifications and found that 28 of them involve short repeated sequences (less than 15 bp), sometimes involving broken homologies. It should be pointed out that although 2 of 30 junctures in the lacI fusions displayed no short homologies, the frequency of these events per available site is far less than this percentage indicates. As calculated in the Materials and methods sections, sites with homologies of $6 \mathrm{bp}$ are approximately 10,000 -fold more prone to duplication-amplifications of the type described in this work. The specific rearrangements detected are representative of the largest available homologies, as picked out by a computer analysis of the homologies between the beginning of the lacI gene and the end of $l a c Y$ and all of $1 a c A$ (data not shown). In summary, large duplications obey the same rules as deletions in E. coli (Farabaugh 1978; Albertini et al. 1982, and references therein), occurring at short sequence repeats, the extent of the repeat influencing the frequency of the event.

The plasticity of the genome displayed by bacterial cells is remarkable. In response to selective pressure, mutants with rearranged genomes emerge easily, fusing inactive genes to distant gene segments by duplication, and subsequently amplifying the number of duplicated copies to upwards of 100, in tandem array. What pathways allow such facile rearrangements? It is of great interest to study the cellular processes involved, since these types of rearrangements mimic those seen in higher eukaryotes in a number of ways. Gene amplification is involved in the expression of resistance to chemotherapeutic drugs in mammalian cells (Schimke 1984|, and the same process is seen to occur during tumor progression in numerous types of cancer (Alitalo 1984; Schwab et al. 1984; Gilbert 1985). Also, oncogene rearrangements often result in a silent gene being placed under the control of a more active promoter (Crew et al. 1982; Kohl et al. 1983; Leder et al. 1983), exactly as seen here in the duplications involving the E. coli lacI-Z fusion system.

The finding that most amplification events in bacteria occur at short repeated sequences provides strong evidence for a model in which the initial event is a duplication mediated by the sequence repeat. Studies in higher cells have led to conflicting models of gene amplification in eukaryotes. For instance, Mariani and Schimke (1984) have proposed that the initial event of amplification is the rereplication of DNA segments within a single cell cycle followed by recombination events. On the other hand, Hahn et al. (1986) suggest that selective treatment may induce aberrant segregation of chromosomal segments which are subsequently amplified, or may cause unequal sister chromatid exchange resulting in gene amplification. This latter model (see also Stark and Wahl 1984) is formally analogous to the sequence of events that we envision for bacterial gene amplification. At this point it is not known if there is a sequence specificity at the junctures of amplified DNA in mammalian cells.

The finding here that large duplications that are highly amplified occur preferentially at short sequence repeats, as do deletions in bacteria, stimulates the consideration of several possible models for the spontaneous generation of these rearrangements.

1. Errors of replication might result from slippage promoted by the short homologies (see Farabaugh et al. 1978; Albertini et al. 1982, and references therein).

2. The rearrangements might represent low-level recombination mediated by one of the known recombination pathways. Many of these pathways in $E$. coli share the requirement for $r e c A$. For instance, $r e c A, r e c B$, and $r e c C$ are involved in general recombination, $r e c A, r e c F$, $r e c I, r u v$, and recN in recombinational repair, and $r e c A$ and $r e c E$ in a supplementary recombination system (see Shen and Huang 1986, and references therein). The sharply reduced frequencies of deletions in $r e c A$ strains has been reported (Albertini et al. 1982).

3 . It is possible that a special enzyme system exists that catalyzes rearrangements at short repeated sequences. This system might also utilize the $r e c A$ function, explaining the partial dependency of deletions and certain duplications on recA. One such system might involve $E$. coli DNA gyrase, which has been shown to mediate recombination and deletion formation in vitro (Ikeda et al. 1982; Jones et al. 1982; Michel and Erlich 1986). Marvo and co-workers have proposed that certain recombination events in vivo are catalyzed by DNA gyrase (Marvo et al. 1983). At this stage, attempts to correlate gyrase cutting sites with the junctures reported here have proven inconclusive.

Future experiments are aimed at distinguishing between the above possibilities. 


\section{Materials and methods}

Isolation of Lac+ revertants of JM177

Overnight cultures of $I M 177$ grown in LB medium (media as described in Miller 1972) were plated on lactose minimal plates. Colonies were picked after $48 \mathrm{hr}$ and purified twice on lactose minimal medium. Single colonies were streaked on lactose-MacConkey plates to determine phenotypic stability. One unstable revertant per culture was analyzed further.

\section{Rapid isolation of DNA for restriction enzyme digestion}

DNA was prepared using a modification of a procedure described in Holmes and Quigley (1981). Bacteria were scraped off minimal lactose plates and thoroughly suspended in $0.35 \mu \mathrm{l}$ of a solution of $8 \%$ sucrose, $0.5 \%$ Triton X-100, $50 \mathrm{mM}$ EDTA $(\mathrm{pH}$ $8.0)$ and $10 \mathrm{~mm}$ Tris- $\mathrm{Cl}(\mathrm{pH} 8.0)$. After the addition of $25 \mu \mathrm{l}$ of freshly prepared lysozyme $(10 \mathrm{mg} / \mathrm{ml}$ in $10 \mathrm{~mm}$ Tris-Cl, $\mathrm{pH} 8.0)$, the samples were boiled for $1 \mathrm{~min}$ and centrifuged at room temperature in an Eppendorf centrifuge for $15 \mathrm{~min}$. The supernatant was transferred to a new tube and extracted twice with buffer-saturated phenol. The DNA was precipitated with ethanol on ice and resuspended in $20 \mathrm{mM}$ Tris (pH 7.5), $1 \mathrm{~mm}$ EDTA. Care was taken throughout the procedure not to vortex at any step. The samples were digested with restriction endonucleases according to the conditions described by the supplier (Pharmacia).

\section{Agarose and acrylamide gels}

DNA restriction fragments were separated by electrophoresis on $1.4 \%$ agarose gels (agarose from Sigma) in Tris, borate, and EDTA buffer (Davis et al. 1980) at 100 volts for 5 hr. Acrylamide gels of $8 \%$ were made as described by Sanger et al. (1977).

\section{Isolation of total E. coli chromosomal/episomal DNA for} DNA sequence analysis

DNA was prepared according to slight modifications of a procedure described by Silhavy et al. (1984). The cells from a 100-ml lactose minimal culture were collected by centrifugation and resuspended in $5 \mathrm{ml}$ of $50 \mathrm{~mm}$ Tris- $\mathrm{Cl}(\mathrm{pH} 8.0), 50 \mathrm{mM}$ EDTA and frozen at $-20^{\circ} \mathrm{C}$. A fresh lysozyme solution $(10 \mathrm{mg} / \mathrm{ml}$ in $0.25 \mathrm{M}$ Tris- $\mathrm{Cl}, \mathrm{pH} 8.0$ ) was prepared and $0.5 \mathrm{ml}$ was added to the frozen cells. The cells were thawed at room temperature and then placed on ice for $45 \mathrm{~min}$. To the chilled cells were added $1 \mathrm{ml}$ of STEP solution $10.5 \%$ sodium dodecyl sulfate, 50 $\mathrm{mm}$ Tris-Cl, $\mathrm{pH} 7.5,0.4 \mathrm{M}$ EDTA, and $1 \mathrm{mg} / \mathrm{ml}$ of proteinase $\mathrm{K}$ ). The mixture was heated at $55^{\circ} \mathrm{C}$ for $60-90 \mathrm{~min}$ with occasional gentle mixing. The mixture was extracted twice with Tris-buffered phenol and twice with chloroform/isoamyl alcohol (24:1). The DNA was precipitated on ice with $1 / 10$ volume of $3 \mathrm{M}$ sodium acetate and 2.5 volumes of cold ethanol. The precipitate was resuspended in $5 \mathrm{ml}$ of $50 \mathrm{~mm}$ Tris- $\mathrm{Cl}(\mathrm{pH} \mathrm{7.5),1 \textrm {mm }}$ EDTA, and $200 \mu \mathrm{g} / \mathrm{ml}$ RNase A and incubated in a shaker water bath at $37^{\circ} \mathrm{C}$ for $2 \mathrm{hr}$. The DNA was precipitated and resuspended in $1 \mathrm{ml}$ of $10 \mathrm{~mm}$ Tris-Cl (pH 7.5), $1 \mathrm{~mm}$ EDTA. In a $200-\mu l$ volume, $150 \mu \mathrm{l}$ of the DNA was digested overnight with HincII restriction endonuclease (Pharmacia). The digestion was phenol-extracted and precipitated with $1 / 2$ volume of $7.5 \mathrm{M}$ ammonium acetate and cold ethanol. The DNA was resuspended in $70 \mu \mathrm{l} 10 \mathrm{~mm}$ Tris- $\mathrm{Cl}$ (pH 7.5), $1 \mathrm{~mm}$ EDTA. Because this procedure yields partially purified $\mathrm{DNA}$, an $\mathrm{OD}_{260}$ reading is not accurate in quantitating DNA yields. Ethidium bromide staining of agarose gels of digested DNA was used to determine what fraction of the DNA prep was necessary for sequence anal- ysis. (Cells grown in rich media result in much higher DNA yields.)

\section{Oligonucleotides}

Sequencing primers of 17 nucleotides were synthesized approximately $150 \mathrm{bp}$ apart throughout the $1 \mathrm{acI}$ gene and used to sequence towards the $5^{\prime}$ end of the gene, across the fusion juncture.

\section{Radioactive kinasing of the DNA sequencing primers}

The synthetic 17-mer oligonucleotides were kinased in a $10-\mu 1$ volume of: $2 \mu \mathrm{l}$ of $60 \mathrm{mM} \mathrm{MgCl}, 1 \mu \mathrm{l}$ of $50 \mathrm{~mm} \mathrm{DTT}, 1 \mu \mathrm{l}$ of 0.5 $M$ Tris (pH 7.6), 30 pmoles oligonucleotide, 5 units of T4 polynucleotide kinase (Pharmacia), and $2 \mu \mathrm{l}(300 \mu \mathrm{Ci})$ of crude $\left[\gamma^{-32}\right.$ P]ATP (ICN Radiochemicals). The reaction was incubated for $1 \mathrm{hr}$ at $37^{\circ} \mathrm{C}$ and transferred to $65^{\circ} \mathrm{C}$ for $10 \mathrm{~min}$ to heat-inactivate the enzyme. The kinased oligonucleotide was purified on a 100- $\mu \mathrm{l} \mathrm{DE}-52$ column (Whatman) poured into a 1-cc syringe. The kinased oligonucleotide was loaded on the column in a $1-\mathrm{ml}$ volume of $50 \mathrm{~mm}$ triethylamine bicarbonate (TEAB) $(\mathrm{pH}$ 8.0). The column was washed several times with $1 \mathrm{ml}$ of $0.2 \mathrm{M}$ TEAB ( $\mathrm{pH} 8.0$ ), until the eluate had low radioactivity. The collected fractions were centrifuged in a Speed Vac Concentrator until all the liquid was evaporated, and the labeled oligonucleotides were resuspended in total volume of $60 \mu \mathrm{l}$ of water.

\section{Sequencing digested, double-stranded, E. coli DNA}

The DNA sequencing reaction is a modification of a protocol by Huibregtse and Engelke (1986). In an Eppendorf tube, the following were combined per sequencing template: $16 \mu \mathrm{l}$ of HincII-digested total $E$. coli chromosomal/episomal DNA (isolated and digested as described above), $5 \times 10^{5} \mathrm{cpm}^{32}$ P-kinased oligo, and water to $65 \mu \mathrm{l}$. The mixture was placed in a $95^{\circ} \mathrm{C}$ water bath for $5 \mathrm{~min}$ and immediately transferred to a $50^{\circ} \mathrm{C}$ water bath. After $30 \mathrm{~min}$ at $50^{\circ} \mathrm{C}, 10 \mu \mathrm{l}$ of $10 \times \mathrm{AMV}$ buffer $(500$ $\mathrm{mM}$ Tris, $\mathrm{pH} 8.0,60 \mathrm{mM} \mathrm{MgCl}, 400 \mathrm{mM} \mathrm{KCl}$ ) was added to the template mixture. The template mixture was equally aliquoted to five tubes labeled $A, T, G, C, X$. (The $X$ tube served as a control for the sequence-specific pausing of the reverse transcriptase enzyme. This tube received all four deoxynucleotides and no dideoxynucleotides in the sequencing reaction.) A $2: 1$ mix of $10 \times$ dATP with $10 \times$ ddATP, $10 \times$ dTTP with $10 \times$ ddTTP, etc., was prepared from $10 \times$ frozen stocks. $(10 \times$ dNTPs: $6 \mathrm{~mm}$ nonlimiting dNTPs, $0.6 \mathrm{~mm}$ limiting dNTPs. $10 \times$ ddNTPs: $0.2 \mathrm{~mm}$ ddNTP.) To the side of tube $A$ was added $4 \mu \mathrm{l}$ of a $2: 1 \mathrm{mix}$ of $10 \times \mathrm{dATP} / 10 \times \mathrm{ddATP}$, and $0.5-1.0$ unit of AMV reverse transcriptase (Pharmacia, IBI, or Seikagaku America, Inc.) diluted in water. Tube $\mathrm{T}$ received $4 \mu \mathrm{l}$ of a $2: 1$ mix of $10 \times \mathrm{dTTP} / 10 \times \mathrm{ddTTP}$ and $0.5-1.0$ units of enzyme; tube $\mathrm{G}$ received $4 \mu \mathrm{l}$ of a $2: 1 \mathrm{mix}$ of $10 \times \mathrm{dCTP} / 10 \times \mathrm{ddGTP}$ and 0.5-1.0 unit of enzyme; and tube $C$ received $4 \mu$ of a $2: 1$ mix of $10 \times \mathrm{dCTP} / 10 \times \mathrm{ddCTP}$ and $0.5-1.0$ unit of enzyme. The tubes were spun for $1 \mathrm{sec}$ in an Eppendorf centrifuge to start the reaction and returned to the $50^{\circ} \mathrm{C}$ water bath. After 30 min, the reaction was stopped by the addition of $4 \mu 1$ of $0.4 \mathrm{M}$ EDTA. Ethanol was added to the tubes and the samples were precipitated on ice for $5 \mathrm{~min}$ and spun in a centrifuge in the cold for $30 \mathrm{~min}$. The pellets were resuspended in $4 \mu 1$ of loading dye (Sanger 1977), heated at $95^{\circ} \mathrm{C}$ for $2 \mathrm{~min}$, and immediately placed on ice. The samples were separated by electrophoresis on an $8 \%$ acrylamide gel. The gel was transferred to Whatman $3 \mathrm{MM}$ paper, covered with plastic wrap, and exposed to Kodak XR5 film with an enhancer overnight at $-70^{\circ} \mathrm{C}$. 
Cloning and sequencing the wild-type HincIl 0.4-kb fragment

A BgIII-PstI fragment from plasmid pGM11 (Galas et al. 1980), which contains the HincII 0.4 fragment, was electroeluted from a $0.7 \%$ agarose gel (Sigma) and subcloned into the BamHI-Pst site in phage M13, mpl8, and mp19 (New England Biolabs). Single-stranded DNA was sequenced as described by Sanger et al. (1977).

\section{Computations}

To determine the sequence homologies between $1 a c I$ and the rest of the lac operon, the sequence was run through the Los Alamos SeqH computer program (Kanehisa 1982). We could discount approximately two-thirds of the homologies the computer identified, because recombinations at those homologies would alter the reading frame and therefore not show up in our genetic selection. We can consider potential homologies in several ways, and with several different criteria. As one example, let us consider the events occurring at homologies of $6 \mathrm{bp}$ (in a row) or greater. In random sequences of DNA a 6-bp repeat will occur at $1 / 4^{6}$ the frequency of any sequence with less than a 6-bp repeat, or $1 / 4096$. If half of the duplications occurred at 6-bp repeats and half did not (a ratio of $1: 1$ ), then the average mutation frequency at a 6-bp repeat site would be 4096 -fold higher than the average frequency at a site with less than a 6-bp homology. In reality, 23 of 30 of the duplications sequenced here occur at 6-bp repeats (a ratio of $3.29: 1$ ). This would give an estimate of a 13,458-fold higher rate per site (on the average), for sites with 6-bp homologies or greater. Of course, this number is even higher for the hotspots among the 6-bp repeat sites.

We can look at the sequences for lacY and lacA and compare them with $l a c I$ sequences for homologies in the parts of $I$ and $Y$ (and all of $A$ ) where we have been able to detect duplicationamplifications. By computer search we have identified 21 homologies of greater than $6 \mathrm{bp}$ in which the resulting fusion would be in the correct translational reading frame. Using the number of bases in the first portion of $I(258 \mathrm{bp})$ and the regions of $Y$ and $A(738 \mathrm{bp})$, we can show that the total number of possible duplication end points is $258 \times 738 \times 1 / 3=63,468$. If we divide the number of occurrences at each type of site by the number of available sites, we get, in the $Y$ and $A$ regions, $7 / 21$ for 6-bp homologies, and $2 / 63,468$ for nonhomologies, or 0.33 and 0.0000315 , respectively. Dividing the first number by the second results in 10,476, which is the factor of increase of rate of duplications occurring at homologies of $6 \mathrm{bp}$ or greater. This is in close agreement with the number calculated from random sequences.

\section{Acknowledgments}

We thank David Galas for advice on statistical analysis, Thomas Southerland for careful preparation of all oligonucleotides, and Karyn Shishido for expert technical assistance. This work was supported by a grant from the American Cancer Society (MV319A) to J.H.M. J.-M.M. was the recipient of a NATO and Philippe Foundation fellowship.

\section{References}

Albertini, A.M. and A. Galizzi. 1985. Amplification of a chromosomal region in Bacillus subtilis. I. Bacteriol. 162: 1203-1211.

Albertini, A.M., M. Hofer, M.P. Calos, and J.H. Miller. 1982. On the formation of spontaneous deletions: The importance of short sequence homologies in the generation of large deletions. Cell 29: 319-328.

Alitalo, K. 1984. Amplification of cellular oncogenes in cancer cells. Med. Biol. 62: 304-317.

Anderson, R.P. and J.R. Roth. 1978a. Tandem chromosomal duplications in Salmonella typhimurium: Fusion of histidine genes to novel promoters. J. Mol. Biol. 119: 147-166.

.1978b. Tandem genetic duplications in Salmonella typhimurium: Amplification of the histidine operon. I. Mol. Biol. 126: $53-71$.

Anderson, P. and J. Roth. 1981. Spontaneous tandem gentic duplications in Salmonella typhimurium arise by unequal recombination between rRNA (rrn) cistrons. Proc. Natl. Acad. Sci. 78: 3113-3117.

Auerbach, C. 1976. Mutation research. John Wiley \& Sons, New York.

Bostock, C.J. 1984. Chromosomal changes associated with changes in development. I. Embryol. Exp. Morphol. 83: suppl. 7-30.

Brake, A.J., A.V. Fowler, I. Zabin, J. Kania, and B. Müller-Hill. 1978. $\beta$-Galactosidase chimeras: Primary structure of a lac repressor- $\beta$-galactosidase protein. Proc. Natl. Acad. Sci. 75: $4824-4827$.

Büchel, D.E., B. Gronenborn, and B. Müller-Hill. 1980. Sequence of the lactose permease gene. Nature 283: 541-545.

Cairns, J. 1981. The origins of human cancers. Nature 289: 353-357.

Calos, M.P. 1978. DNA sequence for a low level promoter of the lac repressor gene and an "up" promoter mutation. $\mathrm{Na}$ ture 274: 762-765.

Calos, M.P., J.S. Lebkowski, and M.R. Botchan. 1983. High mutation frequency in DNA transfected into mammalian cells. Proc. Natl. Acad. Sci. 80: 3015-3019.

Calos, M.P. and J.H. Miller. 1980. DNA sequence alteration resulting from a mutation impairing promoter function in the lac repressor gene. Mol. Gen. Genet. 178: 225-227.

Crews, S., R. Barth, L. Hood, J. Prehn, and K. Calame. 1982. Mouse c-myc oncogene is located on chromosome 15 and translocated to chromosome 12 in plasmacytomas. Science 218: $1319-1321$.

Davis, R.W., M. Thomas, J. Cameron, T.P. St. John, S. Sherer, and R.A. Padgett. 1980. Rapid DNA isolations for enzymatic and hybridization analysis. Methods Enzymol. 65: 404-411.

Deretic, V., P. Tomasek, A. Darzins, and A.M. Chakrabarty. 1986. Gene amplification induces mucoid phenotype in rec-2 Pseudomonas aeruginosa exposed to kanamycin. $J$. Bacteriol. 165: 510-516.

Edlund, T., T. Grundstrom, and S. Normark. 1979. Isolation and characterization of DNA repetitions carrying the chromosomal $\beta$-lactamase gene of Escherichia coli K12. Mol. Gen. Genet. 173: 115-125.

Edlund, T. and S. Normark. 1981. Recombination between short DNA homologies causes tandem duplication. Nature 292: $269-271$.

Farabaugh, P.J. 1978. Sequence of the lacl gene. Nature 274: 765-769.

Galas, D.J., M.P. Calos, and J.H. Miller. 1980. Sequence analysis of Tn9 insertions in the lacZ gene. J. Mol. Biol. 144: 19-41.

Gilbert, F. 1985. Chromosome abnormalities, gene amplification, and tumor progression. Adv. Neuroblastoma Res. $151-159$.

Hahn, P., L.N. Kapp, W.F. Morgan, and R.B. Painter. 1986. Chromosomal changes without DNA overproduction in hydroxyurea-treated mammalian cells: Implications for gene amplification. Cancer Res. 46: 4607-4612.

Haselkorn, R., J.W. Golden, P.J. Lammers, and M.E. Mulligan. 
1986. Developmental rearrangement of cyanobacterial nitrogen-fixation genes. Trends Genet. 2: 225-259.

Hediger, M.A., D.F. Johnson, D.P. Nierlich, and I. Zabin. 1985. DNA sequence of the lactose operon: The lacA gene and the transcriptional termination region. Proc. Natl. Acad. Sci. 82: 6414-6418.

Holmes, D.S. and M. Quigley. 1981. A rapid boiling method for the preparation of bacterial plasmids. Anal. Biochem. 114: 193-197.

Horns, R.C., Jr., W.J. Dower, and R.T. Schimke. 1984. Gene amplification in a leukemic patient treated with methotrexate. J. Clin. Oncol. 2: 2-7.

Huibreqtse, J.M. and D.R. Engelke. 1986. Direct identification of small sequence changes in chromosomal DNA. Gene 44: $151-158$.

Ikeda, H., I. Kawasaki, and M. Gellert. 1984. Mechanism of illegitimate recombination: Common sites for recombination and cleavage mediated by $E$. coli DNA gyrase. Mol. Gen. Genet. 196: 546-549.

Jones, I.M., S.B. Primrose, and S.D. Ehrlich. 1982. Recombination between short direct repeats in a recA host. Mol. Gen. Genet. 188: 486-487.

Kanehisa, M.I. 1982. Los Alamos sequence analysis package for nucleic acids and proteins. Nucleic Acids Res. 10: 183-196.

Kohl, M.E., N. Kanda, R.R. Schreck, G. Bruns, S.A. Latt, F. Gilbert, and F. Alt. 1983. Transposition and amplification of oncogene related sequences in human neuroblastomas. Cell 35: 359-367.

Land, H., L.F. Parade, and R.A. Weinberg. 1983. Cellular oncogenes and multi-step carcinogenesis. Science 222: 771-778.

Leder, P., J. Battey, G. Lenbir, C. Moulding, W. Murphy, H. Potter, T. Stewart, and R. Taub. 1983. Translocations among antibody genes in human cancer. Science 222: 765-771.

Long, E.O. and I.B. Dawid. 1980. Repeated genes in eukaryotes. Annu. Rev. Biochem. 49: 727-764.

Mariani, B.D. and R.T. Schimke. 1984. Gene amplification in a single cell cycle in chinese hamster ovary cells. J. Biol. Chem. 259: 1901-1910.

Marvo, S.L., S.R. King, and S.R. Jaskunas. 1983. Role of short regions of homology in intermolecular illegitimate recombination events. Proc. Natl. Acad. Sci. 80: 2452-2456.

Marx, J.L. 1984. Oncogenes amplified in cancer cells. Science 223: 40-41.

Mekalanos, J.J. 1983. Duplication and amplification of toxin genes in Vibrio cholerae. Cell 35: 253-263.

Michel, B. and S.D. Ehrlich. 1986. Illegitimate recombination at the replication origin of bacteriophage M13. Proc. Natl. Acad. Sci. 83: 3386-3390.

Miller, J.H. 1972. Experiments in molecular genetics. Cold Spring Harbor Laboratory, Cold Spring Harbor, New York.

Miller, J.H., J.S. Lebkowski, K.S. Greisen, and M.P. Calos. 1984. Specificity of mutations induced in transfected DNA by mammalian cells. EMBO J. 3: 3117-3121.

Morrison, A. and N. Cozzarelli. 1979. Site specific cleavage of DNA by $E$. coli DNA gyrase. Cell 17: 175-184.

Müller-Hill, B. and J. Kania. 1974. Lac repressor can be fused to $\beta$-galactosidase. Nature 249: 561-563.

Mulligan, M.E. and W.R. McClure. 1986. Analysis of the occurrence of promoter sites in DNA. Nucleic Acids Res. 14: $109-126$.

Murnane, J.P. 1986. Inducible gene expression by DNA rearrangements in human cells. Mol. Cell. Biol. 6: 549-558.

Riley, M. and A. Anilionis. 1978. Evolution of the bacterial genome. Annu. Rev. Microbiol. 32: 519-560.

Sager, R., I.K. Gadi, L. Stephens, and C.T. Grabowy. 1985. Gene amplification: An example of accelerated evolution in tu- morigenic cells. Proc. Natl. Acad. Sci. 82: 7015-7019.

Sanger, F., S. Nicklen, and A.R. Coulson. 1977. DNA sequencing with chain-terminating inhibitors. Proc. Natl. Acad. Sci. 74: 5463-5467.

Schimke, R.T. 1984. Gene amplification in cultured animal cells. Cell 37: 705-713.

Schimke, R.T., S.W. Sherwood, A.B. Hill, and R.N. Johnston. 1986. Overreplication and recombination of DNA in higher eukaryotes: Potential consequences and biological implications. Proc. Natl. Acad. Sci. 83: 2157-2161.

Schwab, M., K. Alitalo, H.E. Varmus, M.J. Bishop, and D. George. 1983. A cellular oncogene (c-Ki-ras) is amplified, overexpressed, and located within karyotypic abnormalities in mouse adreno cortical tumor cells. Nature 303: 497-501.

Schwab, M., J. Ellison, M. Busch, W. Rosenau, H.E. Varmus, and J.M. Bishop. 1984. Enhanced expression of the human gene $n-m y c$ consequent to amplification of DNA may contribute to malignant progression of neuroblastoma. Proc. Natl. Acad. Sci. 81: 4940-4944.

Segal, E., P. Hagblom, H.S. Seigert, and M. So. 1986. Antigenic variation of gonococcal pilus involves assembly of separated silent gene segments. Proc. Natl. Acad. Sci. 83: 2177-2181.

Shapiro, J.A. 1983. Mobile genetic elements, 688 pp. Academic Press, New York.

Shen, P. and H.V. Huang. 1986. Homologous recombination in Escherichia coli: Dependence on substrate length and homology. Genetics 112: 441-457.

Silhavy, T.J., M.L. Berman, and L.W. Enquist. 1984. Experiments with gene fusions. Cold Spring Harbor Laboratory, Cold Spring Harbor, New York.

Spradling, A.C. 1981. The organization and amplification of two chromosomal domains containing drosophila chorion genes. Cell 27: 193-201.

Stark, G.R. and G.M. Wohl. 1984. Gene amplification. Annu. Rev. Biochem. 53: 447-491.

Tlsty, T.D., A.M. Albertini, and J.H. Miller. 1984. Gene amplification in the lac region of E. coli. Cell 37: 217-224.

Tonegawa, S. 1983. Somatic generation of antibody diversity. Nature 302: 575-581.

Tonegawa, S., H. Sakano, R. Maki, A. Traunecker, G. Heinrich, W. Roeder, and Y. Kurosawa. 1981. Somatic reorganization of immunoglobin genes during lymphocyte differentiation. Cold Spring Harbor Symp. Quant. Biol. 45: 839-858.

Van der Ploeg, L.H., A.W. Cornelissen, P.A. Michels, and P. Borst. 1984. Chromosome rearrangements in Trypanosoma brucei. Cell 39: 213-221.

Varmus, H.E. 1984. The molecular genetics of cellular oncogenes. Annu. Rev. Genet. 18: 553-612. 


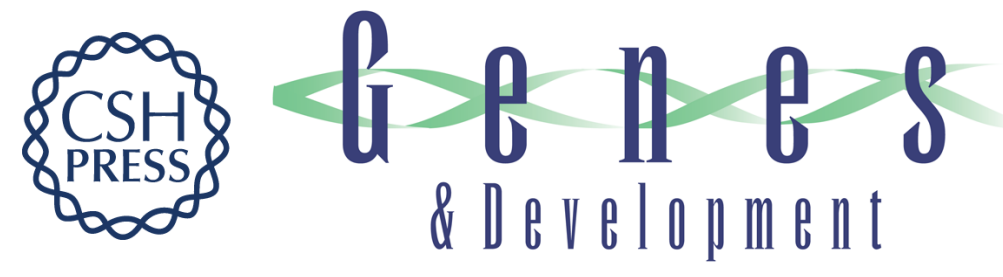

\section{Genetic rearrangements and gene amplification in Escherichia coli: DNA sequences at the junctures of amplified gene fusions.}

S K Whoriskey, V H Nghiem, P M Leong, et al.

Genes Dev. 1987, 1:

Access the most recent version at doi:10.1101/gad.1.3.227

References This article cites 59 articles, 23 of which can be accessed free at:

http://genesdev.cshlp.org/content/1/3/227.full.html\#ref-list-1

License

Email Alerting Receive free email alerts when new articles cite this article - sign up in the box at the top Service right corner of the article or click here.

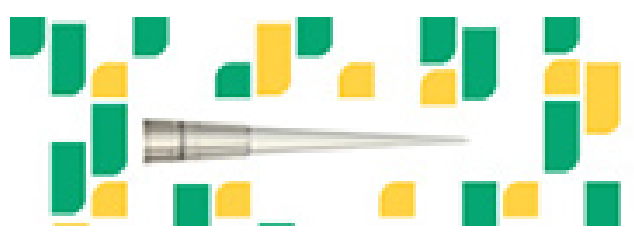

Focused on your science. 